University of Nebraska - Lincoln

DigitalCommons@University of Nebraska - Lincoln

Community and Regional Planning Program:

Faculty Scholarly and Creative Activity

Community and Regional Planning Program

2009

\title{
Mitigating greenhouse gas emissions through local land use planning
}

Zhenghong Tang

University of Nebraska - Lincoln, ztang2@unl.edu

Christopher Hussey

University of Nebraska-Lincoln

Follow this and additional works at: https://digitalcommons.unl.edu/arch_crp_facultyschol

Part of the Urban, Community and Regional Planning Commons

Tang, Zhenghong and Hussey, Christopher, "Mitigating greenhouse gas emissions through local land use planning" (2009). Community and Regional Planning Program: Faculty Scholarly and Creative Activity. 14. https://digitalcommons.unl.edu/arch_crp_facultyschol/14

This Article is brought to you for free and open access by the Community and Regional Planning Program at DigitalCommons@University of Nebraska - Lincoln. It has been accepted for inclusion in Community and Regional Planning Program: Faculty Scholarly and Creative Activity by an authorized administrator of DigitalCommons@University of Nebraska - Lincoln. 
P50.12

Mitigating greenhouse gas emissions through local land use planning

Zhenghong Tang, C Hussey

University of Nebraska, Community and Regional Planning Program, Lincoln, NE, USA

Land use and land use planning have profound implications for greenhouse gas emission (GHG). Local land use planning is well suited to play a critical leadership role in addressing the effects of climate change by encouraging change in development patterns to reduce GHG emissions and their impacts. Although some studies have begun to discuss the role of local land use planning in climate change, little research has been conducted to determine how to convert the concepts of climate change into local land use planning tools and empirically integrate climate change mitigation and adaptation strategies into local land use planning. The objective of this study is to examine how land use relates to reduction of greenhouse gas emission. The specific research questions include: 1) To what extent is GHG mitigation through land use planning policies in rapid growing areas? 2) What are the most influential land use planning variables to GHG mitigation? 3) How can local jurisdictions be improved to address climate change in their plans? The descriptive results indicate that current local jurisdictions have very low awareness for GHG reduction in their land use plans. Additionally, they make limited analysis to detect the relationship of GHG emission and land use development. The positive findings are that some land use planning policies have been adopted to reduce GHG in current land use plans. The regression results indicate that some external variables (e.g. education, technical support) rather than the contextual factors significantly influencing local capacity for GHG reduction. This study will provide important information for decision makers interested in mitigating the adverse impacts of global climate change on local communities. Key words: greenhouse gas emission (GHG), climate change, local, land use planning 